\title{
Physical Fitness Profile of Wheelchair-Bound Soldier: A Preliminary Study
}

\author{
Endang Ernandini' ${ }^{1}$, Trevino A. Pakasi²
}

${ }^{1}$ The Ministry of Defense's Rehabilitation Center, Republic of Indonesia

${ }^{2}$ Department of Community Medicine, Faculty of Medicine Universitas Indonesia

\begin{abstract}
Introduction: The Regulation of the Ministry of Defense No. 106 of 2016 regulates the process of whether a disabled soldier should retire or continue their career. Some soldiers can continue after undergoing a rehabilitation program and fitness test called Uji Kesamaptaan. Unfortunately, the current scoring system in Uji Kesamaptaan only fits for normal soldiers. The purpose of this study was to describe the profile of normal and disabled soldiers who underwent physical fitness tests. The equality value "Kesamaptaan table" with the running test can be used to assess the ability for disabilities by using a wheelchair test?
\end{abstract}

Methods: This preliminary study used a cross-sectional method and involved 46 soldiers who were divided into two groups, disabled $(\mathrm{n}=16)$ and normal $(\mathrm{n}=30)$. All participants underwent a 12-minute run or wheel test in a 400-meter track, to record the distance covered according to their ability. $\mathrm{VO}_{2} \mathrm{Max}$ assessed using the Cardio-Pulmonary Exercise Test (CPET). Results were analyze using SPSS program; Independent T-test.

Results: No significant difference was observed in the characteristics (age, body weight, height, and mass index) between the two groups. The $\mathrm{VO}_{2} \mathrm{Max}$ difference between normal soldiers and disabled soldiers was highly significant. The highest score among disabled and normal soldiers was $38 \mathrm{~L} / \mathrm{min} / \mathrm{kg}$ BW and $64 \mathrm{~L} / \mathrm{min} / \mathrm{kg} \mathrm{BW}$, respectively. Normal soldiers covered $465 \mathrm{~m}$ farther in a 12 -minute run test.

Conclusion: Kesamaptaan, the current scoring system for soldiers, can be considered unfair for the disabled soldiers. The scoring system only includes for 12-minutes running test. Differences in the involvement of muscles and muscle type, affecting energy use and oxygen consumption between the 12-minute run test and wheelchair pedal test. Therefore, value conversion is required for disabled soldiers.

Keywords: disabled persons, exercise test, physical fitness, $\mathrm{VO}_{2} \mathrm{Max}$ 


\section{ABSTRAK}

Latar Belakang: Peraturan Menteri Pertahanan Nomor 106 tahun 2016 telah mengatur proses pensiun atau tidak untuk militer yang disabel karena cedera dalam tugas. Beberapa dapat kembali bekerja setelah menjalani rehabilitasi dan uji kebugaran jasmani yang disebut Kesamaptaan. Nilai Kesamaptaan saat ini hanya ada satu standard yang berlaku bagi tentara normal. Tujuan dari penelitian ini adalah untuk mendeskripsikan profil tentara yang melalui uji kebugaran jasmani A dengan metode berlari dan menggunakan kursi roda.

Metode: Penelitian pendahuluan ini menggunakan metode potong lintang dan melibatkan 46 tentara yang dibagi menjadi dua kelompok. Enam belas tentara dengan disabilitas dan tiga puluh tentara normal. Semua partisipan melalui uji 12 menit berlari atau mengayuh kursi roda, sesuai kapasitas, di jalur lintas sepanjang $400 \mathrm{~m} . \mathrm{VO}_{2}$ Max dinilai menggunakan uji latihan kardiopulmonal (Cardio-Pulmonal Exercise Test, CPET).

Hasil: Secara karakteristik (usia, berat badan, tinggi badan, dan indeks massa tubuh) tidak terdapat perbedaan signifikan diantara dua kelompok. Secara sangat signifikan, perbedaan $\mathrm{VO}_{2} \mathrm{Max}$ didapatkan dari dua kelompok. Skor $\mathrm{VO}_{2} \mathrm{Max}$ tertinggi di kelompok tentara yang disabel adalah $38 \mathrm{~L} / \mathrm{min} / \mathrm{kgBB}$ dan untuk tentara normal adalah $64 \mathrm{~L} / \mathrm{min} / \mathrm{kgBB}$.

Kesimpulan: Penggunaan standar nilai tunggal pada Kesamaptaan yang diberlakukan bagi tentara normal maupun dengan disabilitas mungkin bisa jadi tidak adil karena perbedaan profil dasar secara fisiologisnya. Oleh karena itu, konversi nilai diperlukan bagi tentara dengan disabilitas.

Kata Kunci: kesamaptaan, prajurit difabel, tes berlari 12 menit, tes mengayuh kursi roda, $\mathrm{VO}_{2} \mathrm{Max}$

\section{Correspondent Detail:}

\section{Endang Ernandini}

Email: ernandiniebeb@gmail.com

The Ministry of Defense's Rehabilitation Center, South Jakarta, Indonesia.

\section{INTRODUCTION}

Physical fitness (PF) is one's ability to execute daily activities with optimal performance, endurance, and strength without any noticeable fatigue. Health-related physical fitness has five components to be assessed, which are body composition, muscular strength and endurance, motoric function, metabolic function, and cardiorespiratory fitness. The body composition of an individual is by body mass index (BMI), waist circumference (WC), and skin folds. Muscular strength can be measured using a tensiometer while muscular endurance is measured based on the maximal number of repetitive movements (eg. sit-ups, push-ups, pull-ups). Cardiorespiratory fitness is reflected by peak $\mathrm{VO}_{2}$ after doing a suitable test. The metabolic function is assessed through blood pressure and biochemical analysis such as lipid profile and plasma glucose. ${ }^{1,2}$ Physical fitness is required to work in the field of the military because soldiers have roles, functions, and duties for military operations. ${ }^{3}$ The duty, however, has a lot of potential risks for 
injury, from minor to major injury, resulting in disabled soldiers.

Regulation of the Ministry of Defense of The Republic of Indonesia Number 11 in the year 2016, stated that the disabled soldier caused in a military operation would be classified into the level I (mild), II (moderate), and III (severe). The disabled soldier who belongs to level III will be dismissed with respect from the military. Those who belong to level II and level I might continue their duty after the integrated rehabilitation program at The Ministry of Defense's Rehabilitation Center (Pusrehab Kemhan). The integrated rehabilitation program aims to regain military capability, military sports, or military administration. After the program, the disabled soldiers are categorized into 'return to work', 'return to sport', and whenever possible 'return to combat'. ${ }^{4}$ Therefore, physical fitness tests are required to evaluate the progress following the integrated rehabilitation program, and to determine whether the disabled soldiers can continue their duty in the military. ${ }^{1}$

In the Indonesian military (TNI), the tests to determined a soldier's physical fitness is called Uji Kesamaptaan. Their score in Uji Kesamaptaan is needed for promotion. This is also applied to disabled soldiers. Uji Kesamaptaan consists of several tests called Garjas A, B, and C. Garjas A is done to evaluate the cardiorespiratory fitness level by Cooper's 12-minute running test. Garjas B to evaluate muscle strength and endurance by doing repetitive movements, such as lunges, standing broad jump, vertical jump, shuttle run, sit-up, and squat. Garjas $\mathrm{C}$ is done by breaststroke-swimming style in a 50-meter swimming pool to assess the soldiers' agility. Uji Kesamaptaan score will be taken every six months to assess daily body fitness, as well as appropriateness for promotion. ${ }^{5,6}$
The problem is how to assess the capability of the disabled soldiers when they were no longer able to run as there is no adjustment in the $\mathrm{Uji}$ Kesamaptaan. A conversion value is needed to find the adjustment between a normal soldier compared with wheel-chaired disabled soldiers. This preliminary study is aimed to examine the physical fitness test for wheel-chaired soldiers, to propose a new standard for disabled soldiers.

\section{METHOD}

This preliminary cross-sectional study was aimed to compare the physical fitness between normal soldiers and disabled soldiers.

Forty-six Indonesian military soldiers who take the Uji Kesamaptaan were divided into normal group and disabled group. Inclusion criteria for normal soldier was able to do Kesamaptaan while for disabled group was able to independently pedal a wheelchair. Exclusion criteria for normal soldiers is if their previous Uji Kesamaptaan score were below average-results (final score $<61$ ) in the past six-month. As for the disabled soldiers, they were excluded if they had any comorbidity such as hypertension or cardiovascular-related problems known from the last electrocardiography. They were also excluded if they had balance disorder equivalent to spinal cord injury type $\mathrm{A}$ and $\mathrm{B} \mathrm{NL}$ above tenth thoracal.

A 400-meter running track was used to test the TNI soldiers, with markers at $10-\mathrm{m}$ intervals to measure the distance covered. ${ }^{7}$ In 12 minutes, the normal groups were ordered to run, while the disabled groups were ordered to pedal the wheelchair according to their ability. Every participants were using CPET while doing the test. 
All subjects were ordered to run or to pedal the wheelchair for 12 minutes using a Cardio Pulmonary Exercise Test (CPET). After that, the distance covered by the participants was measured. CPET will show the result of oneminute ventilation (VE), tidal volume (VT), breathing frequency (RR), oxygen uptake $\left(\mathrm{VO}_{2}\right)$, carbon dioxide production $\left(\mathrm{VCO}_{2}\right)$, and end-tidal oxygen $\left(\mathrm{ETO}_{2}\right)$.

No ethical clearance was needed because the subjects were following routine medical military tests. All data were treated confidentially. We informed the subjects about the risk and benefit of the test before the tests.

\section{RESULTS}

Participants' nutritional status was assessed with mean results of $68.1 \pm 8.2 \mathrm{Kg}$ for the bodyweight, $170 \pm 5.2 \mathrm{~cm}$ for the height, and $23.5 \pm 2.2 \mathrm{Kg} / \mathrm{m}^{2}$ for the body mass index. No significant difference was observed for all indicators between the two groups (Table 1).

Table 1. Characteristics of the Military Subjects

\begin{tabular}{lccc}
\hline Variables & $\begin{array}{c}\text { Disabled* } \\
\mathrm{n}=16\end{array}$ & $\begin{array}{c}\text { Normal* } \\
\mathrm{n}=30\end{array}$ & $\begin{array}{c}\text { TOTAL } \\
\mathrm{n}=46\end{array}$ \\
\hline Age (year) & & & \\
Mean age $\pm \mathrm{SD}$ & $29.6 \pm 5.9$ & $26.9 \pm 5$ & $27.9 \pm 5.4$ \\
Min-Max of age & $28.5(22-41)$ & $25(21-41)$ & $27(21-41)$ \\
Body Weight (Kg) & & & $68.1 \pm 8.2$ \\
Mean BW \pm SD & $69.4 \pm 10.1$ & $67.3 \pm 6.9$ & $68(55-95)$ \\
Min-Max body weight & $69(55-95)$ & $67(58-86)$ & $170 \pm 5.2$ \\
Height (cm) & $170.2 \pm 5.9$ & $170 \pm 4.8$ & $169(163-189)$ \\
Mean height $\pm \mathrm{SD}$ & $169(164-189)$ & $170(163-180)$ & \\
Min-Max height & & & $23.5 \pm 2.2$ \\
Body Mass Index $\left(\mathrm{Kg} / \mathrm{m}^{2}\right)$ & $23.9 \pm 2.5$ & $23.3 \pm 2$ & $23.4(19.7-28.7)$ \\
Mean BMI $\pm \mathrm{SD}$ & $24.3(19.7-28.1)$ & $23.1(20.1-28.7)$ & \\
Min-Max BMI & & & \\
\hline
\end{tabular}

*no significant difference between the two groups were observed (independent t-test, $p>0.05$ )

The 2007-2013 surveys of Indonesians health survey research (Riskesdas) showed that $66,1 \%$ of population samples were classified as normal nutritional status. Riskesdas 2018 reported the increasing proportion of overweight $8,6 \%$ to $13,6 \%$, and obese $10,5 \%$ to $21,8 \%$ in society since $2007 .{ }^{8-10}$ The participant of this study could represent Indonesian society by comparing the nutritional status of the study samples and Riskesdas samples.

Normal soldiers' nutritional status in the United States, Belgium, Brazil, and even Afghanistan was categorized as overweight. A study in the 
United States reported those with disabilities were more likely to be obese. ${ }^{11}$ A study upon disabled people in Italy differentiated nutritional status among physical only-impairment with ones plus cognitive impairment. ${ }^{12}$ Each group's mean BMI was classified as overweight even if the data was combined. The score for the physicalonly impairment group was $25,2+4,0 \mathrm{~kg} / \mathrm{m}^{2}$.
Anthropometric profiles of Brazilian soccer players who were amputated shows a mean body weight of $62,5 \mathrm{Kg} / \mathrm{m}^{2}$, similar to the subjects in this study.

There was a highly significant difference in $\mathrm{VO}_{2} \mathrm{Max}$ between the normal groups and the disabled as shown in Table 2.

Table 2. Result of the Physical Fitness Test

\begin{tabular}{|c|c|c|c|}
\hline Variables & $\begin{array}{c}\text { Disabled } \\
n=16\end{array}$ & $\begin{array}{c}\text { Normal } \\
n=30\end{array}$ & $\begin{array}{c}\text { TOTAL } \\
n=46\end{array}$ \\
\hline \multicolumn{4}{|c|}{$\mathrm{VO}_{2} \operatorname{Max}(\mathrm{L} / \mathrm{min} / \mathrm{Kg} \mathrm{BW})$} \\
\hline Mean $\mathrm{VO}_{2} \mathrm{Max} \pm \mathrm{SD}$ & $24.2 \pm 5.9^{*}$ & $53.3 \pm 6.9^{*}$ & $42.4 \pm 15.6$ \\
\hline Min-Max of $\mathrm{VO}_{2}$ Max & $22.5(17-38)$ & $54(40-64)$ & $49(17-64)$ \\
\hline \multicolumn{4}{|c|}{ Qualification of $\mathrm{VO}_{2} \mathrm{Max}(\%)^{* *}$} \\
\hline Very poor & $9(56.3)$ & 0 & $9(19.6)$ \\
\hline Poor & $5(31.3)$ & 0 & $5(10.9)$ \\
\hline Fair & $2(12.5)$ & 0 & $2(4.3)$ \\
\hline Good & 0 & $14(46.7)$ & $14(30.4)$ \\
\hline Excellent & 0 & $16(53.3)$ & $16(34.8)$ \\
\hline \multicolumn{4}{|l|}{ Distance (m) } \\
\hline Mean distance $\pm \mathrm{SD}$ & $2033 \pm 542.5 \mathrm{I}$ & $2528 \pm 96.4$ Í & $2306.2 \pm 440.4$ \\
\hline Min-Max distance & $2168(1296-2800)$ & $2530(2320-2750)$ & $2500(1296-2800)$ \\
\hline
\end{tabular}

*highly significant difference (independent t-test, $\mathrm{p}=0.000$ ); Í significant difference (Mann-Whitney U test, $\mathrm{p}=0.008$ ); **significant difference of proportion (Fisher Exact - test, $\mathrm{p}=0.000$ )

The highest $\mathrm{VO}_{2} \mathrm{Max}$ score for disabled soldiers was $38 \mathrm{~L} / \mathrm{min} / \mathrm{Kg} \mathrm{BW}$ meanwhile the lowest score for normal soldiers was $40 \mathrm{~L} /$ $\mathrm{min} / \mathrm{Kg} \mathrm{BW}$. As a result, the mean $\mathrm{VO}_{2} \mathrm{Max}$ in normal soldiers can be classified into five groups (which is excellent, good, fair, poor, and bad) meanwhile, in disabled soldiers the mean $\mathrm{VO}_{2} \mathrm{Max}$ can only be classified into three groups (fair, poor, and bad). This would be further explained in the discussion. A highly significant difference was also shown in the distance covered between two groups, almost a half kilometer (495m).

There is no specific data on the VO2Max score in normal Asian people. A similar study using Cooper's 12-minute run test in India showed the mean $\mathrm{VO}_{2} \mathrm{Max}$ score in male were $49.9+6,6$ $\mathrm{mL} / \mathrm{min} / \mathrm{kg} \mathrm{BW}$, lower than the results of normal soldiers in this study. ${ }^{13}$ 


\section{DISCUSSION}

In this study, the differences between running tests by normal soldiers and pedaling wheelchair tests by disabled soldiers are shown by: ${ }^{1}$ The highly significant difference in $\mathrm{VO}_{2} \mathrm{Max}$ between two groups. The maximum $\mathrm{VO}_{2} \mathrm{Max}$ in the disabled group only $45 \%$ of the maximum $\mathrm{VO}_{2} \mathrm{Max}$ in the normal group. ${ }^{2}$ A significant difference in $\mathrm{VO}_{2} \mathrm{Max}$ proportion classification. ${ }^{3}$ A significant difference in distance covered, $495 \mathrm{~m}$.

Previous studies explained that the arm muscles tend to be fatigue more easily than the leg muscles when doing high-intensity activities. Arm muscle activities increase cardiovascular work higher than leg muscle activities. The maximum pulse rate will be higher in arm muscle activities than leg muscle activities. ${ }^{14}$

Arm muscle has a lower oxidative capacity than leg muscle according to the study by Huazhong University Laboratory of Science and Technology Brotton Change Center for Biomedical Photonics, in Wuhan 2010. Another study by L. Aron et al (2004) at the University of California examined the achievement of $\mathrm{VO}_{2} \mathrm{Max}$ in healthy athletes. The subjects were asked to running on a treadmill, static biking, and pedaling a static wheel-chair until high-intensity activities reached. The results for maximum $\mathrm{VO}_{2} \mathrm{Max}$ were $44.4 \mathrm{ml} / \mathrm{kg} / \mathrm{min}$ in running, $36.8 \mathrm{ml} / \mathrm{kg} / \mathrm{min}$ in static cycling, and only $28.6 \mathrm{ml} / \mathrm{kg} / \mathrm{min}$ in pedaling. In other words, static cycling $\mathrm{VO}_{2}$ Max score only $83 \%$ compared to running $\mathrm{VO}_{2} \mathrm{Max}$ score, meanwhile pedaling wheelchair only $64 \%$ compared to running.
Another study shows that routine exercise could improve maximal heart rate and $\mathrm{VO}_{2} \mathrm{Max}$. Exercise or any activities using arm muscles tend to be fatigue more easily than activities using leg muscles. ${ }^{15}$ Arm muscle work generally resulted in $60-85 \%$ of maximal aerobic power due to relatively smaller muscle mass. Normal individuals only need around $50 \%$ of total muscle mass to elicit $\mathrm{VO}_{2} \mathrm{Max}$ 's highest potential. ${ }^{16}$ Furthermore, the validity and reliability of predicted $\mathrm{VO}_{2} \mathrm{Max}$ from Cooper's 12-minute run test in healthy adults tend to lower if the score was low and higher if the score was high. ${ }^{13}$ Another study in India recommended modification on Cooper's 12-minute run test before using the test as a method to evaluate cardiorespiratory fitness levels in Asia. ${ }^{17}$

The significant difference in $\mathrm{VO}_{2} \mathrm{Max}$ score between the two groups showed that the current scoring system in Uji Kesamaptaan could not be used to evaluate the disabled. The different use of muscle groups in disabled soldiers and normal soldiers made the scoring system invalid. Arm muscles had fast-twitch muscle fibers, while leg muscles had slow-twitch muscle fibers. The leg muscle fiber contained more myoglobulin and capillaries than the arm muscle. This results in higher oxygenation in leg muscles. Histological analysis showed the relation between ATPase myosin activity with the speed of muscle contraction or the type of muscle fibers. In humans, hydrolysis of ATPase myosin in fast-twitch muscle fibers had two to three times bigger than slow-twitch muscle fibers. ${ }^{18}$ 
The results show that the current scoring system in Uji Kesamaptaan needs to be modified for the disabled soldiers. Another modality is needed in measuring the physical fitness level in disable soldiers. This modality has been proposed by other studies, whether based on laboratory or field activities. The subjects of the studies mostly are wheelchair basketball player athletes. ${ }^{19}$

\section{CONCLUSION}

This preliminary study proves that thereis adifference in the result of Uji Kesampataan running compared to pedaling a wheelchair. This is known from the difference in the mean distance of up to $495 \mathrm{~m}$ which is statistically significant. This preliminary study also proves the distance from running test is farther than pedaling a wheelchair. It can be concluded that a revision of Uji Kesampataan's table scoring system is needed for soldiers with disabilities who perform the test using a wheelchair. So that further research is needed.

\section{ACKNOWLEDGMENTS}

The study was done with the support of the Rehabilitation Center of the Ministry of Defense (Pusrehab Kemenhan). EE did all the examination and the data collection, whereas TP helped analyze the data and the discussions.

\section{REFERENCE}

1. Gellman MD, Turner JR. Encyclopedia of Behavioral Medicine. New York: Springer; 2013.
2. Cabeza-ruiz R, Javier F, Ruiz-gavil I, Manuel A. Feasibility and Reliability of a Physical Fitness Test Battery in Individuals with Down Syndrome. 2019;(Id).

3. Presiden Republik Indonesia. UndangUndang Republik Indonesia Nomor 34 Tahun 2004 Tentang Tentara Nasional Indonesia. 34 Indonesia; 2004 p. 32.

4. Kementerian Pertahanan. Berita Negara: Peraturan Menteri Pertahanan Republik Indonesia Nomor 11 Tahun 2016 Tentang Tata Cara Pemberian Santunan dan Tunjangan Cacat Prajurit Tentara Nasional Indonesia. 2016.

5. Lembaga Administrasi Negara. Modul Pelatihan Dasar Calon PNS: Kesamaptaan. 2017.

6. Sekolah Staf dan Komando Angkatan Darat. Petunjuk Pelaksanaan tentang Penyelenggaraan Seleksi Tahap II Calon Siswa DIKREG LVI SESKOAD TA 2018. Republic of Indonesia; 2018.

7. Mabes AD Dinas Jasmani. Buku Pedoman tentang Tes Kesegaran Jasmani Prajurit dan Calon Prajurit. Bandung; 2019. 50 p.

8. Litbangkes Kementerian Kesehatan. Riset Kesehatan Dasar (Riskesdas) 2007. 2008.

9. Litbangkes Kementerian Kesehatan. PokokPokok Hasil Riskesdas Indonesia 2013. 2013.

10. Litbangkes Kementerian Kesehatan. Hasil Utama RISKESDAS 2018. 2018.

11. Weil E, Wachterman M, Mccarthy EP, Davis RB, Day BO, Iezzoni LI. Obesity Among Adults With Disabling Conditions. 2015;288(10):1265-8.

12. Bertoli S, Battezzati A, Merati G, Margonato V. Nutritional status and dietary patterns in disabled people. 2006.

13. Enry JATP, Ilcox ANRW. Validity and Reliability Analysis of Cooper's 12-minute 
Run and the Multistage Shuttle Run in Healthy Adults. 2011;25(3):597-605.from: www.nsca-jscr.org

14. Evans CH. Exercise Testing for Primary Care and Sports Medicine Physicians. White RD, editor. Springer; 2009; 417 p.

15. Goosey-tolfrey VL, Tolfrey K, Gooseytolfrey VL, Tolfrey K. Journal of Sports Sciences The multi-stage fitness test as a predictor of endurance fitness in wheelchair athletes wheelchair athletes. 2008;37-41.
16. Hoffman MD. Cardiorespiratory Fitness and Training in Quadriplegics and Paraplegics. 1986;330:312-30.

17. Bandyopadhyay A. Validity of Cooper's 12-minute run test for estimation of maximum oxygen uptake in male university students. Biol Sport. 2015;32(No1):59-63.

18. Dendir S. When do soccer players peak? A note. J Sport Anal. 2016;2:89-105.

19. Goosey-tolfrey V. Bases Physiological Testing Guidelines : The Disabled Athlete. In 2008. 